\title{
OFF-FARM EARNINGS: THE IMPACT OF ECONOMIC STRUCTURE
}

\author{
Kevin T. McNamara and Lewell F. Gunter*
}

Changes in the structure of agriculture in the United States during the past 30 years have had dramatic impacts on the allocation of time of members of farm families to farm and nonfarm activities. In 1960, 42 percent of the income of farm families came from nonfarm sources. By 1983 the proportion had grown to 72 percent (USDA, 1984). Nonfarm income has become a major factor in determining the economic well being of farm families and the rural communities in which they reside.

Off-farm income has important implications for agriculture. Huffman (1980), Lyson (1986), and Simpson and Kapitany (1983), argue that off-farm income provides an important way for new entrants to agriculture to meet the high capital costs involved in the establishment of a farm. Others (Bollman, 1979; Lee, 1965; Sumner, 1982), adopting a Neoclassical approach, contend that the allocation of farm labor to off-farm activities increases as the marginal returns to off-farm work becomes greater than the returns to farm work. Johnson (1985) suggests that off-farm income also can provide valuable supplemental income for small farm operators with limited farm income.

Local economic structure, or opportunities to earn nonfarm income, should have significant implications for farm family income (Findeis, 1988). This paper reports the results of an analysis of the off-farm earnings of Georgia and Oklahoma farm operators. Unlike earlier studies, this analysis examines the relationship between the economic region in which a farm operator resides and his allocation of labor to non farm activities. The following section of the paper presents the theoretical basis for the analysis. This is followed by sections on the empirical model, the data, the results and the conclusions.

\section{A Conceptual Model for Off-farm Earnings}

Neoclassical theory has provided the conceptual basis for earlier studies of the off-farm earnings of farm operators (Lee, 1965; Bollman, 1979; Huffman, 1980; Sumner, 1982; Simpson and Kapitany, 1983; Johnson,

\footnotetext{
"Assistant Professor and Rural Development Economist, Department of Agricultural Economics and Institute of Community and Area Development, and Associate Professor, Department of Agricultural Economics, respectively, University of Georgia, Athens, Georgia 30602.
}

1985). The farm operator is assumed allocate his time between farm and nonfarm work and nonwork activities to maximize his utility. The operator allocates his time to these three classes of activities so that the marginal values of the last unit of time devoted to each activity are equal (Sumner, 1982). Farm operator characteristics, farm and family characteristics, and local and labor market conditions influence the value of the time of farm operators in each activity (Lass, 1988).

Huffman (1980) presented a graphical representation of the time allocation decisions of farmers (Figure 1). The demand curve for farm labor is given by line FF'. The demand curve for off-farm labor is represented by WOF. The labor supply curve is depicted by STST'. The off-farm labor supply curve is indicated by BSOF. The farm operator allocates OX time to off-farm labor and OT time to farm labor, allocating a total of OS time to labor activities.

Huffman discussed the effects of changes in farm output, nonwage income, human capital, and other factors on the allocation of labor between farm and nonfarm activities. Huffman did not examine explicitly the impact of the structure of the local economy on the labor allocation decisions of farmers. Local economic structure affects such allocation decisions by its influence on local off-farm labor demand.

A decline in off-farm labor demand can have an ambiguous effect on total and off-farm labor supplied. A decline in the wage rate will result in fewer hours of labor supplied as leisure is substituted for labor, but the income effect is ambiguous. The upward sloping labor supply curves in Figure 1 are consistent either with a positive income effect or with a negative income affect that is dominated by the substitution effect. A sufficiently large decrease in the off-farm rate will result in a decrease in both total and off-farm labor supplied. For example, a decrease in the off-farm wage from W and W1 in Figure 1 would result in a reduction in off-farm labor supplied of OX OX1. Total labor supplied would decline from OS to OS1. Farm labor would increase from OT to OT1.

If the initial off-farm wage rate were below B, no offfarm labor would have been supplied. A reduction in the off-farm wage rate below $B$, therefore, would have no impact on either off-farm or total labor allocation. 


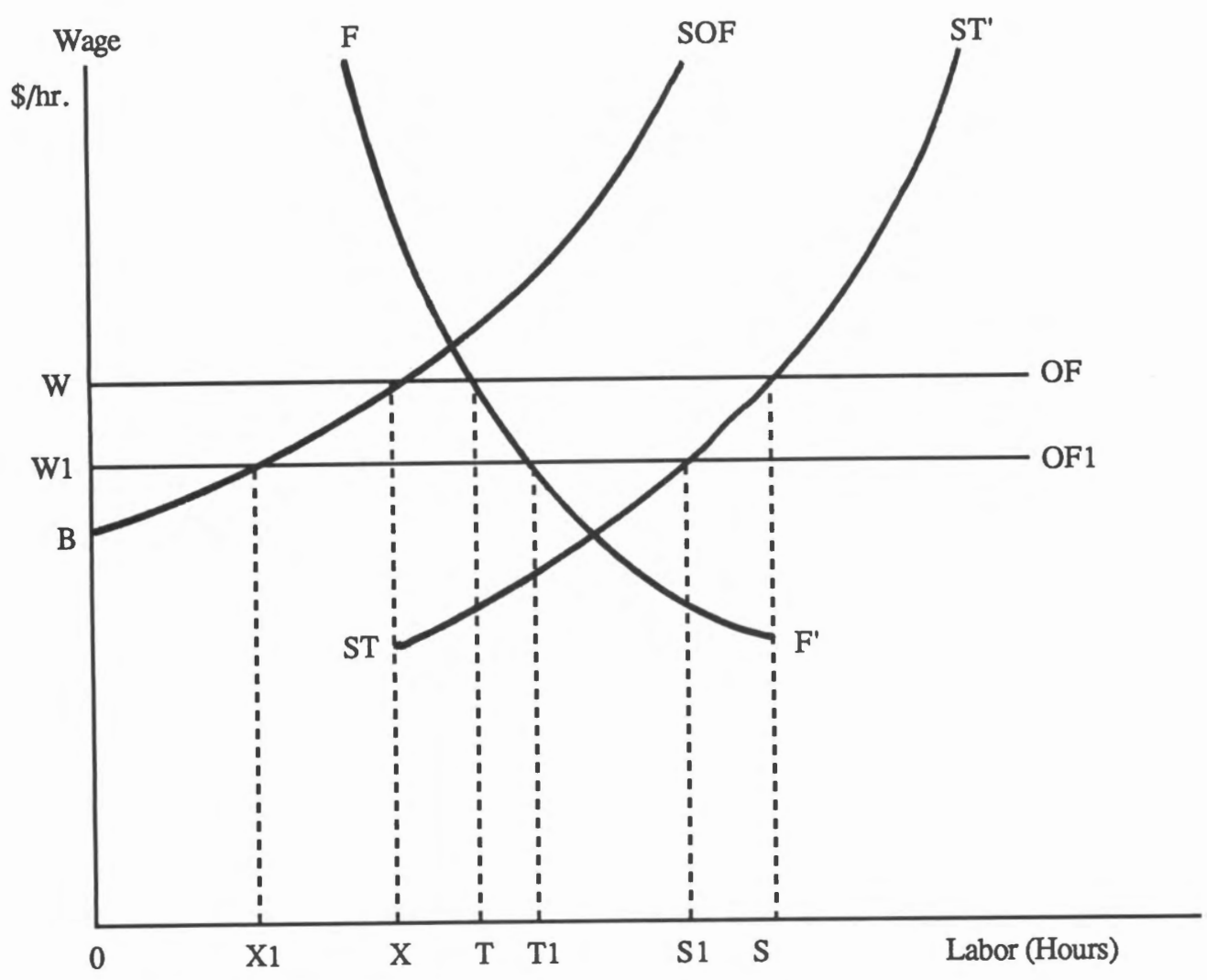

Figure One. Graph of the time allocation decisions of a farmer

\section{Labor Market Characteristics}

Local labor market characteristics can influence the off-farm labor allocation decisions of farm operators in two ways. First, as indicated above, wage rates influence allocations of labor between farm and nonfarm activities. Second, local labor market characteristics can influence off-farm labor allocation opportunities. High unemployment and underemployment can constrain the off-farm employment opportunities of farmers. Various labor market characteristics also may constrain off-farm labor opportunities (Killingsworth, 1983). A diverse labor market might provide farm operators the flexibility to allocate labor to off-farm labor activities around the inflexible labor requirements of farming operations. A less diverse local labor market, however, could constrain farm operators to the degree that they could not allocate labor to non-farm activities during such low farm labor demand periods as evenings or nights.

The impact of local labor market characteristics has been recognized in earlier off-farm labor allocation studies. The impacts of local labor market characteristics have not been integrated into the empirical models, however. Huffman (1980) included a dummy variable for state of residence in his analysis as a proxy for potential local differences in labor market structure. Sumner (1982) included dummy variables for location and distance to a major city in his analysis to control for the influence of jobrelated commuting and labor market differences.

\section{Data}

The data used in the analysis were from public use micro-data sample D of the 1980 Census of Population and Housing (PUMS-D) (USDC, 1983). The PUMS-D sample was one percent of the long-form Census of Population data. The data identified individuals by geographic region with respect labor market area (LMAs) rather than by state, MSA, or Census division as was done for the three other 1980 public-use files. The LMAs for Sample D were formulated using cluster analysis of employment commuting patterns (Tolbert and Killian, 1987). LMAs containing one or more counties in Georgia or Oklahoma were selected for this analysis. There were 19 LMAs in Georgia and 12 in Oklahoma (Figures 2 and 3). Farm households were identified as places that had more than $\$ 1,000$ in gross agricultural sales in 1979. There were observations for 768 farmers in the 31 LMAs. 


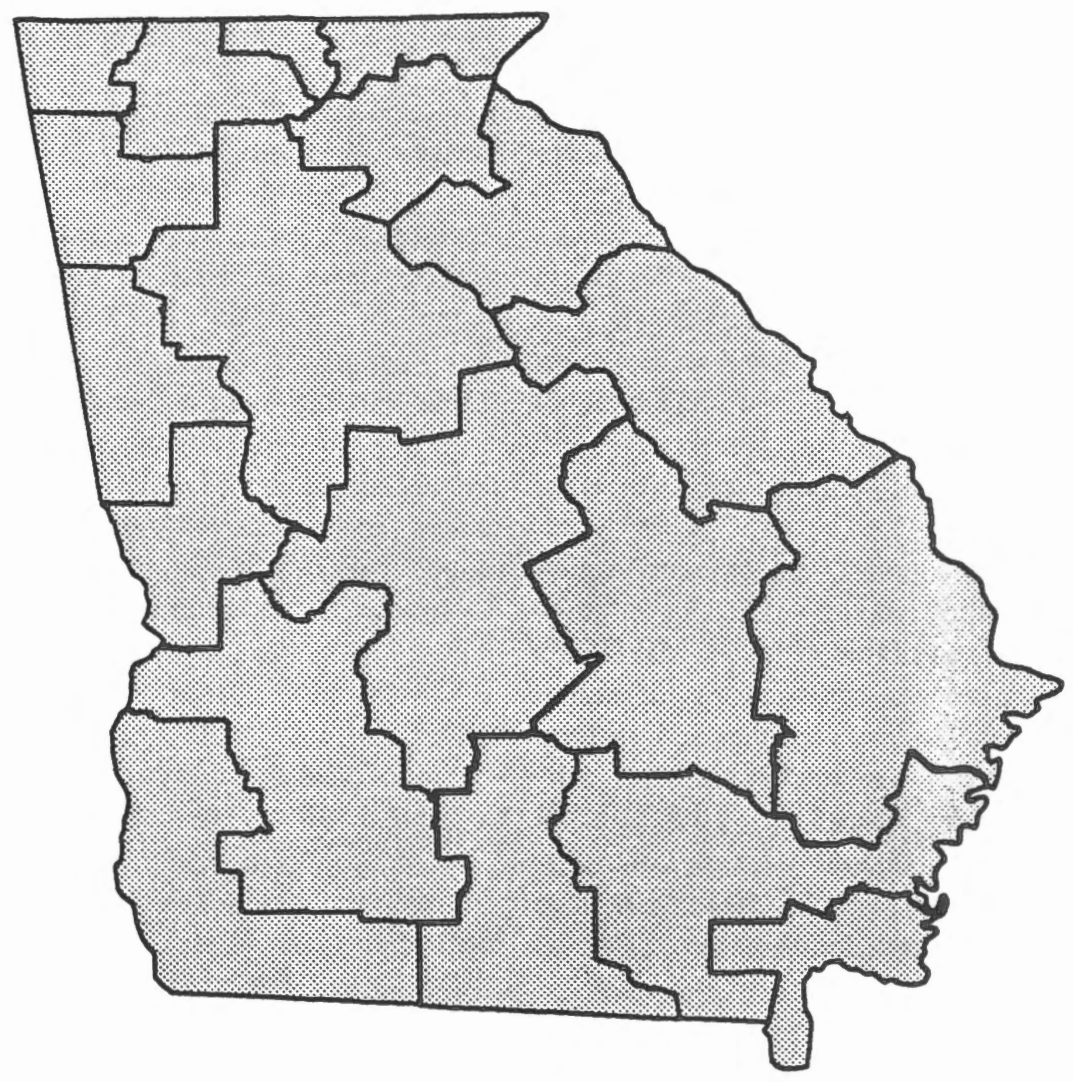

Figure Two. Georgia Labor Market Areas

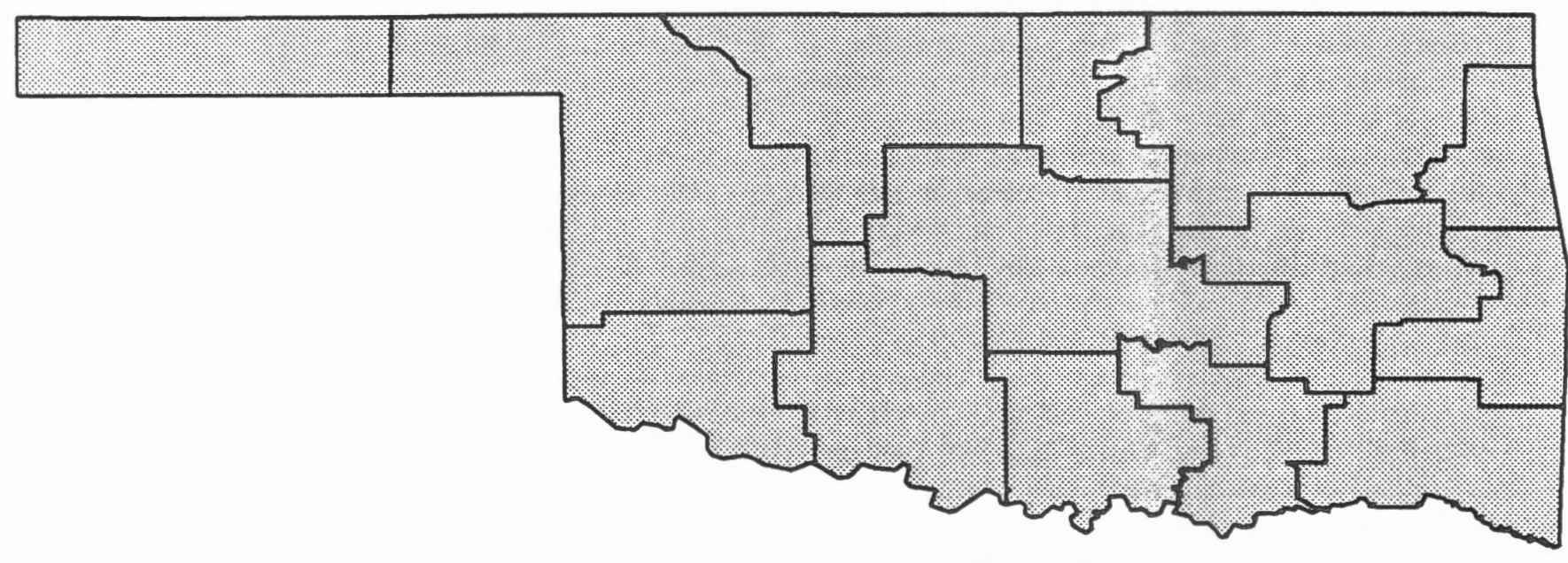

Figure Three. Oklahoma Labor Market Areas

Source: Tolbert and Killian

Mapped by The Institute of Community and Area Development, UGA 


\section{Empirical Model}

Off-farm earnings or labor supply models generally include variables to measure individual producer attributes, farm characteristics, household characteristics and local labor market factors (Bollman, 1979; Huffman, 1980; Lee, 1965; Simpson and Kapitany, 1983; Singh, 1983; Sumner, 1983). The model specified below is consistent with those employed in earlier studies. An attempt has been made, however, to improve measurement of local labor market characteristics to gain more insight into the influence of the local economy on farm labor allocation decisions.

An off-farm earnings model was estimated rather than an off-farm labor supply model since data on hours worked off farm were not available in the PUMS-D data set. The dependent variable was constructed as the sum of two components, wage and salary income and non-farm self employment income of the head of household. Offfarm wage and salary earnings decisions may differ from nonfarm self-employment decisions because of differences in the nonhuman physical capital of the farmers. Due to data limitations, however, these decisions were assumed to be jointly determined.

\section{Individual Producer Attributes}

The attributes of farm operators used in this analysis were similar to those used in earlier studies. Sex and race were included as dummy variables, and were assigned a value of 1 for female and nonwhite, respectively. Being female or nonwhite was hypothesized to have a negative association with the off-farm earnings of the operator.

Four variables were included in the analysis as measures of the human capital of the farm operator's. Educational attainment, a commonly used measure for human capital accumulation, was included. The variable, last year of schooling completed, was hypothesized to have a positive relationship with off-farm earnings. Age was included as a measure of human capital to represent investments in human capital investments associated with experience. Both linear and quadratic age terms were included in the model. As in previous studies, the linear component was hypothesized to have a positive association with earnings. The quadratic term was expected to have a negative relationship with earnings.

The existence of a disability also was included in the model as a human capital measure. A dummy disability variable was given a value of 1 if the operator had a disability. A disability was hypothesized to have a negative association with off-farm earnings because it would reduce access to employment.

\section{Family Characteristics}

Family characteristics have been included in offfarm labor allocation models because of the possible impact of household factors on the marginal value of the time of the farm operator in various uses. The family can affect both demand for the labor of the operator and the supply of farm labor available.

Family income from sources other than the farm influences the marginal utility of the farm income, and therefore, the labor-leisure tradeoff for the farm operator. Other income included investment income, transfer payments, and income of other family members from any source. Net farm income also was included as "other" income as it can vary independently of gross farm income. These factors have been associated with negative income effects in earlier labor supply studies (DeVanzo et al., 1976; Sumner, 1982). A negative relationship between other income and off-farm income of the operator was hypothesized.

Family size, the number of persons in the family of the operator, was included in the model. Family size influences family income needs as well as farm labor availability (Sumner, 1982). The increased income requirements should increase the marginal value of the time of the operator in both farm and nonfarm activities. The availability of family labor on the farm may increase the value of the labor of the operator off-farm labor while reducing its value on the farm. The presence of children also may increase the marginal utility of the labor of the operator in the household or of leisure time. Both Huffman (1980) and Sumner (1982) found a positive relationship between family size and off-farm labor supply.

\section{Farm Characteristics}

Differences in characteristics of farms influence the off-farm labor allocation decisions of farmers. Farm size, enterprise mix, and capitalization all can influence the availability -amount, season and time of day-of labor from a farmer for off-farm employment. The PUMS files provided no information about farming operations other than on income. The simultaneous estimation of farm and off-farm earnings functions, therefore, was not possible.

The absolute value of farm income was included in the empirical model as a measure of farm size. As noted above, net farm earnings were included ion the other income variable. The absolute value of farm income was assumed to be a measure of farm labor demand. It was hypothesized that larger farms require greater allocations of managerial time to farm work than smaller farms. Operators of larger farms, therefore, would have less 
flexibility in allocating labor to off-farm activities. Farm size is believed to be related more directly to the absolute value of farm income than to net farm income. While net farm income captures the effect of farm income on offfarm labor allocation, it may not reflect farm size accurately. This is especially true in cases of negative net farm incomes. The absolute value of farm income was assumed to be a superior size indicator to the extent that smaller farms are likely to have smaller profits or losses.

The effect of the inability simultaneously to estimate farm and off-farm earnings due to data constraints remains problematic. It introduces the possibility that simultaneous equation bias may be associated with the inclusion of the farm size measure in the estimating equation. This clearly is a limitation of using the PUMS data files, but hopefully the bias introduced is not great. To the extent that farm size is predetermined by fixed assets such as land and machinery, the simultaneity problem is reduced.

\section{Local Labor Market Effects}

Local labor market characteristics influence the offfarm earnings of farmers by affecting employment opportunities and off-farm wage rates. Data from the PMUS files on labor force status and employment, by industry, were used to construct local labor force characteristics. Values for each of the labor market variables were constructed for each of the 31 LMAs in the study area.

The unemployment rate was calculated as the percentage of the civilian labor force in each LMA that was classified as unemployed in e census. A high unemployment rate was hypothesized to be associated with more limited local off-farm employment opportunities. A nega- tive relationship between the unemployment rate and offfarm earnings was hypothesized.

Individual industry data by LMA were used to construct industrial structure matrices for all LMAs. The technical documentation for the PUMS files includes 231 individual industry codes (USDC, 1983). Individual industry codes are classified into several industry groups and sub-groups. Table 1 lists the nine industrial groups used in this analysis. Each of these industrial codes was included in the off-farm earnings model to represent the percentage of employees working in that industry group in the particular LMA. There were no a priority expectations with respect to the income effect of these industry variables. The variables were included to test for the effect of industry structure on off-farm earnings.

A dummy variable was incorporated in the model to test whether there were differences in off-farm earnings between farm operators in Oklahoma and Georgia. The dummy variable was assigned a value of 1 for operators from Oklahoma and a value of 0 for operators from Georgia.

\section{Estimation and Results}

Two econometric problems were encountered in the estimation of the off-farm earnings model. The first was a sensored data problem associated with the a large number of observations with zero off-farm earnings. The second was multicolinearity associated with industry structure variables.

Ordinary least squares estimation of the earnings model with or without the zero observations results in bias in the estimated coefficients (Judge et al., 1985, p. 780).

Table 1

Industrial Codes Used in Estimating Off-farm Earnings of Georgia and Oklahoma Farmers

\begin{tabular}{llc}
\hline Industry Variable & \multicolumn{1}{c}{$\begin{array}{c}\text { Industry Sub- } \\
\text { Groups Included }\end{array}$} & $\begin{array}{c}\text { Industry S.I.C. } \\
\text { Codes Included }\end{array}$ \\
\hline AG & agriculture, forestry, fisheries & $10-31$ \\
CONS & construction, mining & $40-60$ \\
NDMFG & nondurable manufacturing & $100-222$ \\
DURMFG & durable manufacturing & $230-392$ \\
SALES & wholesale, retail & $500-691$ \\
PERSER & personal services & $761-791$ \\
PROFSER & professional and related services & $812-892$ \\
GOVT & public administration & $900-932$ \\
OTHERS & transportation, communication, utilities & $400-472$ \\
& finance, insurance, real estate, business & $700-712$ \\
& and repair services, entertainment and & $721-760$ \\
& recreation services & $800-802$ \\
\hline
\end{tabular}


The two stage Heckman estimation procedure (Heckman, 1979; Judge et al., 1985) was used to address the censored data problem. This procedure involves the calculation of a profit equation utilizing all observations. The Inverse Mill's ration from the profit equation then is included as a variable in a second stage OLS estimation using only nonlimit observations.

Multicollinearity was encountered among the industrial structure variables. It was not, however, a problem with the other variables. Principal components regression (Sanint, 1982; Judge et al., 1985, p. 909) was used to address the censored data problem. The characteristic root criterion was used to define a subset of principal components explained 93 percent of the variation in the models. OLS coefficients for the principal components in the second stage then were transformed to estimate the coefficients and their standard errors for the original errors for the original industry variables. The SHAZAM econometrics package (White and Horsman, 1985) was used in the analysis.

Results from the probit analysis are presented in Table 2. These are intermediate results that are necessary for the second stage of the off-farm earnings model. The probit results indicate that sex, age, education, disability, other income, farm value, unemployment, and two of the principal components of the industrial structure matrices affected the probability that farm operators earned offfarm income.

Five of the significant coefficients were producer characteristics. The significance of the age measures suggests that increasing age has a positive influence on producer decisions to earnings, supporting the human capital hypothesis. The age squared term was significant and negative, supporting the hypothesis that at some point the human capital depreciates and the probability that procedures will earn nonfarm earnings decreases. The positive sign on the educational attainment measure and the negative sign of the disability measure also support the human capital hypothesis regarding the probability that farmers will earn nonfarm income.

The Farm Value farm characteristic, was significant with a negative sign. This supports the hypothesis that farm size is inversely associated with the decisions of farm operators to earn off-farm income.

Table 2

Probit Analysis of Off-Farm Income of Georgia and Oklahoma Farmers

\begin{tabular}{lcc}
\hline \hline Variable & Coefficient & T-Value \\
\hline Constant & 0.1250 & 0.2689 \\
Sex & -0.4933 & $-4.5108^{*}$ \\
Age & 0.0623 & $3.9791^{*}$ \\
AgeSq & -0.0009 & $-5.7295^{*}$ \\
Education & 0.0354 & $2.8246^{*}$ \\
Race & 0.0176 & 0.4258 \\
Disability & -0.2363 & $-2.2523^{* *}$ \\
No. Children & 0.0104 & 0.2872 \\
Other Income & -0.0036 & -0.8861 \\
Absolute Value Farm Income & -0.0709 & $-11.3170^{*}$ \\
Unemployment Rate & -1.2816 & $-3.7042^{*}$ \\
State & 0.1145 & 0.7594 \\
PC1 & 0.0168 & $1.9280^{* *}$ \\
PC2 & 0.0244 & $2.4749^{*}$ \\
PC3 & 0.0215 & 1.2350 \\
PC4 & -0.0258 & -1.5854 \\
\hline
\end{tabular}

Log-likelihood

Likelihood Ratio Test

Maddala R-square

Percentage Correctly Predicted

Number of Observations
$-900.08$

381.40

0.25

0.73

1315.00

"Significant at .01 level

"Significant at .05 level 
Other income, a family characteristic, was significant and negative. The results indicate that other income reduced the probability of off-farm earnings. This supports the hypothesized relationship between family nonfarm income and off-farm labor allocation. The unemployment variable, a measure of the health of the local labor market, was significant with a negative sign, consistent with the hypothesis. The first two principal components of the industry variables were significant and positively associated with off-farm earnings. These measures cannot be interpreted directly, however. The impact of the industry variables will be discussed with the results of the off-farm earnings regression model.

The results of the estimation of the off-farm earnings regression model are presented in Table 3. The dependent variable in the model was the natural log of off-farm earnings. The coefficients can be interpreted, therefore, as the percentage change in off-farm earnings associated with a unit change in the independent variable.

Four of the five operator attributes were significant, race being nonsignificant. Female farm operators and operators with a disability were associated with off-farm earnings as hypothesized. The age measure was associated positively with off-farm earnings, while the age squared term was negative. The positive education coefficient suggests that an additional year of schooling was associated with a 9.9 percent increase in off-farm earnings.

The other income variable was significant. The variable had a negative sign, consistent with a hypothesized relationship between total farm family income and the offfarm earnings of the farm operator. This result suggests that such off-farm earnings decrease about 1.5 percent with every thousand-dollar increase in family income from all other sources. The other household measure, number of

Table 3

OSL Results of Estimating Off-Farm Earnings of Georgia and Oklahoma Farmers

\begin{tabular}{lcc}
\hline \multicolumn{1}{c}{ Variable } & Coefficient & T-Value \\
\hline Constant & -3.2782 & -3.1936 \\
Sex & -1.1831 & $-5.0142^{*}$ \\
Age & 0.2144 & $6.2775^{*}$ \\
AgeSq & -0.0026 & $-6.0560^{*}$ \\
Education & 0.0990 & $5.8401^{*}$ \\
Race & 0.1031 & 0.0573 \\
Disability & -0.8897 & $-5.6597^{*}$ \\
No. Children & -0.1116 & -0.3451 \\
Other Income & -0.0145 & $-3.2083^{*}$ \\
Absolute Value Farm Income & -0.1154 & $-3.8500^{*}$ \\
Unemployment & -1.9484 & $-3.4387^{*}$ \\
AGFOR & -0.0714 & $-5.1197^{*}$ \\
CONS & -0.0041 & -0.5159 \\
NONDURMAN & 0.0087 & 0.9241 \\
DURMAN & 0.0342 & $2.2110^{* *}$ \\
SALES & -0.0246 & $-3.3648^{*}$ \\
PERSERV & -0.0068 & $-2.9061^{*}$ \\
PROFSERV & 0.0449 & $3.2171^{*}$ \\
OTHERS & 0.0085 & 0.9428 \\
GOVT & 0.0117 & $1.7087^{* * *}$ \\
State & 0.2331 & 1.4490 \\
Inverse Mill's Ratio & 2.5671 & $3.8346^{*}$ \\
\hline \hline
\end{tabular}

"Dependent Variable: Ln Off-Farm Earnings

Adjusted R-Squared $=0.1757$

Significant at .01 Level

*Significant at .05 Level

-*."Significant at .10 Level 
children, was not significant. This variable had been significant in earlier research (Huffman, 1980; Sumner, 1982).

The farm value measure, absolute value of farm earnings, was significant and negative. This supports the hypothesis that operators of larger farms earn less off-farm income. A thousand dollar increase in the absolute value of farm income was associated with an 11.5 percent decline in the off-farm earnings of the operator.

Six of the local labor market variables were significant. The unemployment rate measure was significant wit a negative sign, supporting the hypothesis that off-farm earnings are inversely affected by local unemployment. A 1.0 percent increase in employment in the agriculture, forestry and fisheries sector was associated with a 7.1 percent decline in off-farm earnings. Employment concentrations in sales and personal services also were associated lower off-farm earnings. One percent increases in sales and personal services were associated with 2.5 percent and 0.7 percent declines in off-farm earnings respectively.

Employment concentrations in professional services and in government employment were associated with increased off-farm earnings. A 1.1 percent increase in employment in the professional services sector was associated with a 4.5 percent increase in the off-farm earnings of the farm operator. A 1.0 percent increase in government employment was associated with a 1.2 percent increase in off-farm earnings.

The dummy variable for state was not significant, providing no support for the hypothesis that farmers in Georgia are more likely to earn off-farm income than farmers in Oklahoma, or vice versa.

\section{Summary and Conclusions}

The analysis reported here examined factors associated with the off-farm earnings of farm operators in Georgia and Oklahoma labor markets. The analysis utilized the PUMS-D files, a data base that was designed specifically for analysis of the effects of local labor market on economic activity.

Characteristics of farm operators that have been included in prior off farm labors research were included in the analysis. The coefficients for these variables had the hypothesized signs and generally were consistent with the results of earlier studies. Education and age had positive relationships with off-farm earnings, supporting the idea that the human capital accumulated through education and experience increases the probability that farmers will work off the farm. Having a physical disability and being a female farm operator were negatively associated with offfarm earnings. The race of the operator was not associated with such earnings.
The absence of data on farm characteristics in the PUMS-D file precluded simultaneous estimation of farm and off-farm earnings functions. Farm characteristics were brought into the analysis through net farm income and a gross income measure of farm size, however. To the extent that off-farm earnings in a given year affect farm size for that year, there is the possibility of simultaneous equation bias. The fixity of such assets as owned land and machinery is assumed to predetermine farm size to some unknown degree. The farm size measure, absolute value of farm income, suggests that operators of larger farms are less likely than operators of smaller farms to earn off-farm income.

The significant, negative result for the other income variable suggests a negative income effect. In other words, the higher the income of a farm family from nonagricultural sources, the less likely the operator was to work off the farm.

The results of the local labor market characteristics variables provide new insight into the influence of local economic conditions on off-farm earnings of farmers. While prior studies have found distance from a city and city size to be important determinants of off-farm earnings of farm operators (Sumner, 1982), no earlier study incorporated specific measures of local economic structure.

The significant, negative sign on the unemployment coefficient supports the obvious conclusion: local unemployment lowers local off-farm earnings opportunities. This may reflect both limited employment opportunities and low local wage rates due to high unemployment.

The estimated results of the impact of employment concentrations in various industrial sectors suggest that local labor market characteristics are critically important for the off-farm earnings of farmers. Labor market employment concentrations in professional services, durable manufacturing and government are all positively associated with farm operators' off-farm earnings. Employment concentrations in agriculture, forestry and fisheries, sales and personal services, on the other hand, were associated negatively with the off-farm earnings of farm operators.

The sectors associated positively with off-farm earnings generally are stable, high wage sectors. Durable manufacturing would offer operators flexibility as to time of day worked where plants operate more than one shift, but it would not be expected to offer flexibility as to number of hours worked or in seasonal employment. Professional services and government, the other two sectors associated positively with off-farm earnings, do not necessarily offer employment flexibility.

The sectors associated negatively with earnings generally are low wage sectors that tend to be less stable than the sectors associated positively with off-farm earnings. They also tend to employ low-skill workers. All three of the sectors-agriculture, forestry and fisheries, sales, and 
personal services-would be expected to offer flexibility as to number of hours and time of day worked, however. These sectors also would offer seasonal employment opportunities. The low wage reduces the attractiveness of employment in labor market areas dominated by these sectors, despite the flexibility they offer in number of hours and time of day worked.

Policies providing off-farm earnings opportunities for farm operators to stabilize farm family incomes should take into account the structure of the labor market area. This analysis suggests that a concentration of local employment in high-wage, stable employment increases the off-farm earnings of farmers. Concentration of employment in low-wage, less stable sectors is associated with lower off-farm earnings of farm operators. Efforts to stimulate off-farm employment, it appears, should be concerned with expanding high-wage, stable employment in rural areas in an effort to increase the off-farm earnings of farm operators.

Additional research is needed to identify the types of jobs held by farm operators in stable, high-wage labor markets and the structures of the local economies that are associated with the types of jobs farms hold.

\section{References}

Bollman, R.D. “Off-Farm Work By Farmers: An Application of the Kinked Demand Curve for Labor." Can J. Agr. Econ. 27 (3):37-60, 1979.

DeVanzo, J., D. DeTray, and D. Greenberg. "The Sensitivity of Male Labor Supply Estimates to Choice of Assumptions." The Review of Economics and Statistics 63:313-25, 1976.

Findeis, Jill L. "The Demand for Off-Farm Labor: Implication for Off-Farm Employment Decisions." Paper presented at the Symposium on Multiple Job-Holding Among Farm Families in North America, Arlington, Virginia, May 16, 1988.

Heckman, J. "Sample Selection Bias As A Specification Error." Econometrica 47:153-61, 1979.

Huffman, W. E. "Farm and Off-Farm Work Decisions: The Role of Human Capital." Rev. Econ. and Stat. 62:14-23, 1980.

Johnson, T.G. "Off-Farm Employment of Small-Farm Operators: A Strategy for Survival." Strategy for Survival of Small Farmers: International Implications, Thomas T. Williams, ed. Human Resources Development Center, Tuskegee
Institute, 1985.

Judge, G., Griffiths, W., Hill, R. Luthkepohl, H. and T.C. Lee. The Theory and Practice of Econometrics. 2nd ed. New York: John Wiley and Sons, 1985.

Killingsworth, M. Labor Supply. Cambridge: Cambridge University Press, 1983.

Lass, Daniel A. "Factors Affecting the Supply of Off-Farm Labor." Paper presented at the Symposium on Multiple JobHolding Among Farm Families in North America, Arlington, Virginia, May 16, 1988.

Lee, John E., Jr. Allocating Farm Resources Between Farm and Nonfarm Uses: A Journal of Farm Economics, 47(1): 83-92, 1965.

Lyson, T. A. "Entry Into Farming: Implications of A Dual Agricultural Structure." Chapter 8 in Agricultural Change: Consequences of Southern Farms and Rural Communities, Joseph J. Molnar, ed., Westview Press, Boulder, 1986.

Sanint, L. "Applying Principal Components Regression Analysis to Time Series Demand Estimation." Agricultural Economics Research 34: 21-27, 1982.

Simpson, W. and M. Kapitany. "The Off-Farm Work Behavior of Farm Operators." Amer. J. Agr. Econ., 65 (4): 801-805, 1983.

Singh, Surevdra P. "Part-Time Farm Operators and Supply of Off-Farm Labor by Farm Operators in Rural Areas." Joumal of the Community Development Society, 14(1): 51-61, 1983.

Sumner, D. A. "The Off-Farm Labor Supply of Farmers." Amer. J. Agr. Econ., 64(3): 499-509, 1982.

Tolbert, C. M. and M. S. Killian. Labor Market Areas for the United States. United States Dept. of Agriculture, ERS, ARED. Staff Report AGES 870721, August, 1987.

U.S. Department of Agriculture, Economic Research Service, National Economic Branch. Economic Indicators of the Farm Sector: Income and Balance Sheet Statistics, 1983, December 1984.

U.S. Department of Commerce. Census of Population and Housing, 1980: Public-Use Microdata Samples Technical Documentation. Bureau of the Census, Washington D.C., 1983.

White, K. J., and N. Horseman. SHAZAM. The Econometrics Computer Program. Version 5.0. User's Reference Manual. Dept. Economics, University of British Columbia, Vancouver, B.C., 1985. 